Intersections

Canadian Journal of Music

Revue canadienne de musique

\title{
Contributors / Collaborators
}

Volume 28, numéro 1, 2007

URI : https://id.erudit.org/iderudit/019302ar

DOI : https://doi.org/10.7202/019302ar

Aller au sommaire du numéro

Éditeur(s)

Canadian University Music Society / Société de musique des universités canadiennes

\section{ISSN}

1911-0146 (imprimé)

1918-512X (numérique)

Découvrir la revue

Citer ce document

(2007). Contributors / Collaborators. Intersections, 28(1), 205-207.

https://doi.org/10.7202/019302ar

Tous droits réservés (C) Canadian University Music Society / Société de musique des universités canadiennes, 2007
Ce document est protégé par la loi sur le droit d'auteur. L’utilisation des services d'Érudit (y compris la reproduction) est assujettie à sa politique d'utilisation que vous pouvez consulter en ligne.

https://apropos.erudit.org/fr/usagers/politique-dutilisation/
Cet article est diffusé et préservé par Érudit.

Érudit est un consortium interuniversitaire sans but lucratif composé de l’Université de Montréal, l'Université Laval et l'Université du Québec à Montréal. Il a pour mission la promotion et la valorisation de la recherche. https://www.erudit.org/fr/ 


\section{CONTRibutors / COLlaborators}

Luc Bellemare poursuit présentement des études de doctorat en musicologie à l'Université Laval sous la codirection de Serge Lacasse et de Line Grenier. Boursier du FQRSC, il entend orienter sa thèse sur l'histoire de la musique à la radio québécoise des origines. Parallèlement à ses études, Luc Bellemare est auxiliaire de recherche pour le Centre de recherche interuniversitaire sur la littérature et la culture québécoises (CRILCQ) dans le cadre du projet " Penser l'histoire de la vie culturelle québécoise ».

Sophie Bisson détient un B.A Mus de Queen's University et une maîtrise en musicologie de l'Université de Montréal. Chanteuse de formation, elle s'intéresse à l'opéra canadien du vingtième siècle et le contexte dans lequel il prend forme. Son mémoire de maîtrise, rédigé sous la direction de Michel Duchesneau, évalue l'impact des politiques institutionnelles sur la création dopéra au Canada entre 1980 et 2003.

Claudine Caron est inscrite au doctorat en musicologie à l'Université de Montréal. Elle vient de compléter sa thèse intitulée "Chroniques des concerts du pianiste Léo-Pol Morin (1892-1941) : pour un portrait de la modernité musicale au Québec », sous la direction de Michel Duchesneau. Impliquée au sein de sociétés musicales et dans les réseaux internationaux détudes canadiennes et québécoises, elle a prononcé plusieurs conférences au Canada, aux États-Unis ainsi que dans des pays européens. En 2002, elle publiait Musiques québécoises pour piano solo (recueil pédagogique), en coproduction avec le Centre de musique canadienne. Suivant son double intérêt pour l'histoire de la musique au Canada et l'histoire des pianistes, elle prépare actuellement lédition du journal inédit du pianiste Ricardo Viñes avec la musicologue Nina Gubisch (à paraître aux Presses de l'Université de Montréal) et travaille à l'élaboration d'un projet de recherche sur l'imaginaire du Nord dans la création musicale canadienne.

Christopher Cwynar is presently completing a Masters degree in the Popular Music and Culture program at the University of Western Ontario. His current research concerns the relationship between genre, generation, and nationalism in the discourse pertaining to the Canadian popular music of the 1960s and 1970s.

Robin Elliott studied with Clifford Crawley during his undergraduate years at Queen's University. He is currently a professor of musicology and an Associate Dean of the Faculty of Music at the University of Toronto, where he also holds the Jean A. Chalmers Chair in Canadian Music, is the Director of the Institute for Canadian Music, and is a Senior Fellow of Massey College. 
Kate Galloway is a doctoral candidate in musicology/ethnomusicology at the University of Toronto where she is completing her dissertation which explores the experience and impact of performance space, place and ritual in R. Murray Schafer's Patria cycle. She has recently published reviews in Intersections, The University of Toronto Quarterly, The Journal of Popular Music Studies and Twentieth Century Music. Her paper "Beyond the Ghetto: k-os' Interweaving and Re-plantation of Traditional and Non-Traditional Hip-Hop Signifiers" was recently published in Folk Music, Traditional Music, Ethnomusicology: Canadian Perspectives, Past and Present edited by Anna Hoefnagels and Gordon E. Smith. Her main research areas include Canadian music studies, soundscape, intersections between visual art and music, and the work of R. Murray Schafer, as well as popular music studies in the areas of film music, cover versions, media and music and indie music scenes.

Kristina Guiguet's M.A. thesis (Distinction; Carleton University Medal, 2003) is published as The Ideal World of Mrs. Widder's Soirée Musicale: Social Identity and Musical Life in Nineteenth-Century Ontario, 2004. An English-trained singer, Kristina music directs Ottawa's Shakespeare Young Company (20002007) and is past President of the Ottawa Historical Association (2005-06). Supported by SSHRC, her doctoral dissertation (History, Carleton University) uses concert programmes to compare musical-political culture, 1830 to 1860, in England and colonial Canada. She received an Honorable Mention for the 2007 Pauline Alderman Award for Outstanding Scholarship on Women in Music, in the Reference Book or Research Tool category.

Mary I. Ingraham is Assistant Professor, Musicology at the University of Alberta. She has held positions as Director of Liberal Studies at the Faculty of Extension, University of Alberta, and has taught at Simon Fraser University, and Douglas College. Current teaching includes undergraduate and graduate courses in Canadian Music, choral and orchestral repertoires, and $19^{\text {th }}-21^{\text {st }}$ century topics in music and society. Her primary area of research is the examination of the socio-political context for music creation, including issues of identity and cultural politics in Canadian opera. In addition, she has served as consultant, researcher and writer of several web-based educational projects for the Canadian Music Centre, including sound adventure, Sound Progressions, and Influences of Many Musics.

Friedemann Sallis is a Professor at the Université de Moncton. He took his PhD at the Technische Universität Berlin where he studied with the late Professor Carl Dahlhaus. His writings include a book on the early works of György Ligeti and the co-edition of A Handbook to Twentieth-Century Musical Sketches (Cambridge, 2004), as well as numerous articles on music of the nineteenth and twentieth centuries. Since 1997 he has received three successive research grants from the Social Sciences and Humanities Research Council of Canada.

Titulaire des prix d'Analyse, de Culture Musicale, d'Acoustique Musicale et de Direction de Chœur Grégorien au Conservatoire National Supérieur de Musique de Paris, Brice Tissier est agrégé de musique et prépare actuellement 
un doctorat consacré à la génétique des matériaux chez Pierre Boulez et Michael Jarrell à l'Université de Paris-Sorbonne en collaboration avec l'Université de Montréal. Il enseigne parallèlement l'analyse musicale d'œuvres du $\mathrm{XX}^{\mathrm{e}}$ siècle à l'Université de Paris-Sorbonne en tant quallocataire moniteur, et assure depuis 2003 la direction musicale du Chœur Grégorien de Paris. 